\title{
Bolşevik İhtilâlinden Sonraki Azerbaycan Sahası Türk Edebiyatında Şiir ve Poema Türü
}

\section{Mitat Durmuş*}

Dünya siyasî tarihi üzerinde 1917 Bolșevik İhtilâli'nin önemli bir yeri vardır. Sovyetler Birliği'nin hâkimiyeti altında bulunan Türk Cumhuriyetleri de bu ihtilâlden büyük ölçüde etkilenirler. Rejimin değişmesine bağlı olarak toplum hayatında önemli değişiklikler olur. Yeni bir yaşam üslûbu gelişmeye başlar. 1920 'lerden sonra bu daha da yoğunluk kazanarak devam eder ve 1937'de Stalin'in iktidara gelmesiyle en belirgin şeklini alır.' Bu tarihten başlayarak Azerbaycan'ın toplum yaşamı, idarî şekli değişmekle kalmaz, idarî kadroları da değişir. Yönetime Ruslar ve özellikle Azerbaycan'da yaşayan Ermeniler getirilir. Azerbaycan Türkleri ikinci plana itilmekle birlikte, çoğu bilim adamı, yönetici, gazeteci, öğretmen, yazar, şair de hayatından olur. 1930'lu yıllarda kolektifleştirme devrinde halktan insanların binlercesi yok edilir. Böyle bir yönetimin hüküm sürdüğü dönemde edebiyatın şekillenmesi de bu ölçüler içinde gelişir. Nitekim "Sovyet Azerbaycan Edebiyatı"nın sanat değeri taşıyan eserlere kavuşması belirtilen tarihten yaklaşık $25-30$ yıl sonra kendini gösterir. Resmî ideolojik görüşe uygun eser yazma zorunluluğu vardır ve buna "Sosyalist Gerçekçilik" adı rejim tarafından verilmektedir. Yeni cemiyetin her şeyden evvel yeni bir insan tipine ihtiyaç. duyması ve bu insan tipinin bakışı ile toplum hayatının değerlendirilmesi gereği ortaya çıkar. Yeni insan tipi ile cemíyete "inkılâpçı" bir gözle bakılır; sosyal olaylar, insan ilişkileri sınıflar arasındaki çatışma fikrine uygun olarak açıklanır. Yeni cemiyete, yeni bir insan; yeni insana, yeni bir edebiyat gereği doğal bir gelişmenin sonucu olarak kendini gösterir. Böylece eski insana, eski cemiyete ve eski edebiyata hücum başlamıştır. Bu eski - yeni savaşımının Türkiye sahası Türk edebiyatında da varlığını görürüz. Fakat, Azerbaycan sahasında "eski ile yeni" arasındaki diyalektik savaşımı sadece Bolşevik yazarların yürütmüş olması dikkat çekicidir.

* AÜ Sosyal Bilimler Enstitüsü Türk Dili ve Edebiyatı Ana Bilim Dalı Araştırma Görevlisi

'Meherremov, Nizami; Getsin Gelmesin 1937, Azerneşr, Bakû 1992, s.4 
$\mathrm{Bu}$, eskiyi (klasik olanı) savunacak insanın olmamasından çok, savunmadan sonra yaşama hakkının olmaması ile ilgili bir durumdur. Bolşevik yazarlar tarafından başlatılan ve halkın yararına olduğu söylenen klasik edebiyata hücum, öylesi bir durum alır ki, toplumu anlatacağız derken tüm insanî değerler alt üst edilir. Bu dönemde yazılmış edebî metinlerde klasik yaşamın ve edebiyatın model insan tipini, zalim beyler, hurafeye inanan gafiller, cahil din adamları, zengin kişiler, anti-komünistler temsil eder. Bunların karşısında yenilikten yana öğretmenler, feminist kızlar ve kadınlar, idealist komünist gençler, mübarize (mücadele eden) kahramanlar bulunur. Tematik ve karşıt güçlerin çatışmasında klasik edebiyat taraftarları daima karşıt güç konumundadır. Bu durum öylesine belirginleșmeye başlar ki, edebî eser sloganlar toplamı durumuna gelir.

Dönemin Bolșevik görüșünü destekleyen Azerbaycanlı şair ve yazarlar, bu görüşün, sınıf farklılıkları ortadan kaldırılmalı, fikrinden hareketle, kendi millî dil ve edebiyatlarını inkâr etme aşamasına kadar gelirler; bunun yerine "Lenin'in Dili", "Komünist Dünyasının Dili", "Proleter Dili" ve edebiyat için "Sovyet Azerî Edebiyatı", "Kardaşlıq Edebiyatı", "İnkılap Edebiyatı", "Komünist Halklar Edebiyatı" gibi terimleri sıkça kullanmaya başlarlar. Mayakovski, Mihail Yuryeviç Lermantov, Maksim Gorki gibi şair ve yazarlar resmî model olarak sunulur. Zira Komünist Partisi'nin, işçilere, sosyalizme sadakat ruhu aşılayan eserlere ödül vermesi, eser sahibi şair ya da yazarın yeni bir görevle onurlandırılması, sunulan resmî modelin çabucak kabul görmesine hizmet eder. İhtilâlden önceki kalem sahiplerinden birkaçı, doğru bildikleri yolda devam ederken birkaçı da kalemlerini dönemin ideolojisine sunar. İhtilâlden önceki dönemde söylediklerini ihtilâlden sonra da söyleyen, kendi sanat ve hayat anlayıșlarına göre eser veren şahıslar ise, tam anlamı ile çileye talip olurlar. Bunlar arasında Cafer Cabbarlı, Yusuf Vezir Çemenzeminli, Hüseyin Cavid, Celil Memmedquluzâde... gibi çileyi seçenleri sayabiliriz. 1930 'lardan başlayarak, yeni yetişen genç şair ve yazarlar ile daha öncekiler arasında zamanla artarak süren bir nesil çatışması başlar. Fakat 1940-1941 yıllarına doğru nesil çatışması, fikir ve dünya görüșü çatışmasına dönüșür. "Komunist Partisi"nin beğenisini kazanmak, sosyalist değerlere bağlılığın ölçüsünü göstermek, bu bağlılığın doğurduğu heyecanı bir yerlere aktarabilmek düşüncesi ile dolu olan genç sanatkârlar, bunu yaşlı nesle hücum etmekle bașaracaklarını düșünerek, hakaret sözcükleri ile amaçlarına 
Türk Edebiyatında Şiir ve Poema Türü

ulaşmak isterler. Bu savaşımda partinin de desteğini gören gençler daha başarılı olurlar. Dönemin baskısından dolayı yaşlı nesil eserlerini, ya çok eski tarihi konulurdan ya da uzak ülkelerde meydana gelen olaylardan esinlenerek yazmak durumunda kalır. Konusunu Azerbaycan'ın eski tarihinden alan Yusuf Vezir Çemenzeminli'nin "Gızlar Bulağı" ${ }^{2}$, Cafer Cabbarlı'nın "Od Gelini", Samed Vurgun'un "Zencinin Arzuları" gibi eserler bunlara verilecek örneklerdir. Dönem içinde romanlarda ve öykülerde ișlenen temalar, șiirdekine oranla daha geniș anlatı olanağı bulmuș olmasından, ihtilâl öncesi dönem ve ihtilâl sonrası dönem hayatını anlatmaya hizmet eder. İhtilâl öncesi hayatı anlatan edebî metinlerde zenginlerin sömürü zihniyeti, ağa- emekçi çatışması, din adamlarının cehaleti, köylünün, iş̧̧inin ve aydın gençlerin kötü durumu asıl tema olarak ele alınır. İhtilâl sonrası hayatı anlatan eserlerde ise, Bolşevik rejiminin getirdiği güzellikler anlatılır. Bu dönem eserlerinde yenilikten yana olan insan tipi idealize edilir.

1941-1946 yılları arasında Rusya'nın II. Dünya Savaşı'nda yer alması ve askerî gücünü, egemenliği altında bulundurduğu Türk nüfusundan sağlaması nedeniyle bu dönem edebiyatında yoğun bir şekilde savaş temi işlenir.

1950'li yıllara gelindiğinde özellikle şiir vadisinde önemli değişiklikler olur. Bu dönem genç şairlerinin kendilerine örnek aldığı Samed Vurgun, Resul Rıza, Süleyman Rüstem, Memet Rahim, Mikail Müssfik, Mehdi Seyyidzade'nin yanı sıra Rus şairlerinden A. Tvordaviski, M. Dudu, A. Prokof Lev, M. Lukanin'in işledikleri poema türü, genç şairler için açılan yeni bir kapı olur.

Samed Vurgun'un "Zencinin Arzuları", "Zamanın Bayrağdarı", "Mugan", özellikle "Aygün" poeması; Resul Rıza'nın "Lenin", Süleyman Rüstem'in "Gafur'un Gelbi", Memmed Rahim'in "Leningrad Göylerine" gibi poemaları edebiyatla ilgilenen gençlik için güzel örneklerdir.

Yeni bir tür olarak algılanan poemanın edebî tenkit bakımından cevaplandırılamayan yönleri vardır. 1950'li yıllardan günümüze kadar poema türü etrafında ciddî edebî-bedî̂ tartışmalar yürütülmekte olup, bunlardan bazıları türün sınırlarının çok geniş olmasından diğerleri ise, bu genişliğin edebî bir imkân olarak

${ }^{2}$ Çemenzeminli, Yusuf Vezir; Gızlar Bulağı, Gençlik, Bakû 1972 
Kerim, Nebi Xezri, Eliağa Gürçaylı, Gasım Gasımzade, İslam Seferli, Zeynal Cabbarzade... gibi şairler poema türünün bayraktarlığını yapmaktadırlar.

İlk şiirlerini siyasî buhranlar, savaşlar, cepheye gidip de gelmeyenler ya da cepheye gidiyor adıyla bașka yerlere götürülenler ile, onların geriye bıraktıkları ıstıraplı hayatın etkisi ile yazan Bahtiyar Vahabzade, devrin ve şartların değişmesine bağlı olarak kendini yenilemiş "Modern Azerbaycan Şiiri"nin önemli isimlerinden birisidir. 1960-1965'li yıllarda modern Azerbaycan șiirinde insan ve onun iç dünyası sıkça işlenen tema olur. Şiir, ideolojik söylemlerden büyük ölçüde uzaklaşmıştır. Bahtiyar Vahabzade ile başlayan ve diğerleri tarafından devam ettirilen şu üç özellik 1970'li yılların şiirinde temel ölçüdür:

\section{1- Millîlik \\ 2- Asrîlik \\ 3-Tabiat}

Millîlik konusu içine, vatan sevgisi ve vatandaşlık duygularının estetik anlatımı girer. Bu dönem şiirinde ve genel temayülde vatan temi, Prof. Dr. Yaşar Garayev'in "Vatan sevgisi ve vatandaşlık duygularının estetik aksi, şiirimizde oldukça güçlüdür. Poeziyamızın koro halinde okuduğu türkünün nakaratı sadece ve sadece "Azerbaycan"dır dersek mübalağa yapmış sayılmayız." belirttiği gibi "Azerbaycan" ismi üstünde yoğunlaşır. Tabiị ki kastedilen "Azerbaycan" yalnız Kuzey Azerbaycan için değil Güney Azerbaycan için. de geçerlidir. Çağdaş Azerî şiirinde "Güney Azerbaycan" zaten millî bir mesele olarak ișlenir. ${ }^{10}$ Balaş Azeroğlu, Elì Tüde, Söhrab Tahir, Bahtiyar Vahabzade, Nebi Xezri, Helil Rıza Ulutürk, Eli Kerim gibi şairler bu millî meseleyi en yoğun şekilde ișleyen sanatkarlardır.

Asrîlik konusu içinde ise, millîlik imgesinin sosyal öneme sahip olması ve devrin ihtiyaçlarına cevap vermesi değerlendirilir. Bu iki unsuru bünyesinde bulunduran şiir "İlmi Tekniki Terakki Devri" denilen aşamanın problemlerinden olan "tabiat ve tabiata bakış" sorununu da, her şair, kendi yeteneği ölçüsünde cevaplandırmaya çalışır.

\footnotetext{
Makas, Zeynelabidin; Çağdaş Azerbaycan Şiiri Antolojisi, Kültür Bakanlığı Yayınları Ank. 1992, s.3

${ }^{10}$ Akpınar, Yavuz: a.g.e., s.175
} 
Savaş ve tabiat, çağdaş Azerbaycan şiirinin ve şairlerinin sınavdan geçirildiği iki önemli mihenk tașıdır. Bahtiyar Vahabzade, Nebi Xezri, Helil Rıza Ulutürk, Mehmed Arslan gibi şairler, Azerbaycan tarihine "Kanlı Yanvar" olarak geçen 20 Ocak 1990 tarihindeki Karabağ katliamını konu alan şiirleri ile bu iki unsuru birleştirerek son derece güzel örnekler verirler. Makineleştirilen, robotlaştırılan tabiatı, savaș ve teknolojinin olumsuz etkisinden korumak asıl amaçtır. Lirik şiirlerde tabiatla şair arasında bir yakınlık kurulurken, geçmișten de büyük ölçüde yararlanılır. Nebi Xezri'nin Dede Korkut tiplerini esas alan "Efsaneli Yuhular" poemasını buna örnek verebiliriz. Bu bakımdan "Muğam" tabiatla efsanenin, tarihin ve mûsikînin birleştirdiği yer olur. Mehmed Araz, Tevfik Bayram, Gasım Gasımzade gibi șairler ve özellikle Bahtiyar Vahabzade'nin "Muğam" ve Hüseyin Arif (Hüseyinzade)'nin "Dilgam" adlı poemaları bu görüșümüze en güzel örnekleri teșkil eder. Mil, Muğan, Göy Göl, Gökçe Karabağ... gibi yer adları, artık çağdaş şiirde sadece coğrafi yer adı olmaktan çıkmış, bir güzellik anlayışına, bir ahlakî ölçüye dönüşmüş ve bu yönü ile toplumun manevî geçmişinin ve kahramanlık tarihinin ebedileşmesine vesile olmuştur. Azerbaycan İlimler Akademisi Başkanı Prof. Dr. Yaşar Garayev milletimizin güzel ahlâka sahip olmasını, tabiatın ahlâkını tasvir etmekten ileri geldiğini söyler: "Müdrik atalarımızın güzel ahlâk sahibi olmalarının sebebi, belki de tabiatın ahlâkını tasvir etmelerinden ileri gelmektedir"."

Çağdaș Azerbaycan șiirinin özellikle son yıllarında, "köy-șehir" teminin çoğunlukla işlenmeye başladığını görmekteyiz. Genç nesil arasında bir nostalji olarak yayılan köy ve köy hayatına duyulan özlem, zamanla şehir/lerin varlığını unutturur hale gelmiştir. Eliağa Gürçaylı, Sabir Rüstemhanlı, Vagıf Nesib, Gasım Gasımzade, Musa Yakub, Memmed İsmail, Cingiz Elioğlu... gibi sanatçılar, şehrin monoton ve koșușturmalarla geçen hayatına, köy kırlarında yașanan bir anlık bir mutluluğu tercih ederler.

İhtilâlden sonra başlayan ideolojik söylemlerin, 19651970 'li yıllarda azalmaya başladığını ve $2000^{\prime} l_{ı}$ yıllara gelindiğinde bireysel olarak işlendiğini, şair ve yazarların daha çok millî ve estetik kaygılar içinde olduğunu söyleyebiliriz.

"Makas, Zeynelabidin; a.g.e., s.3 


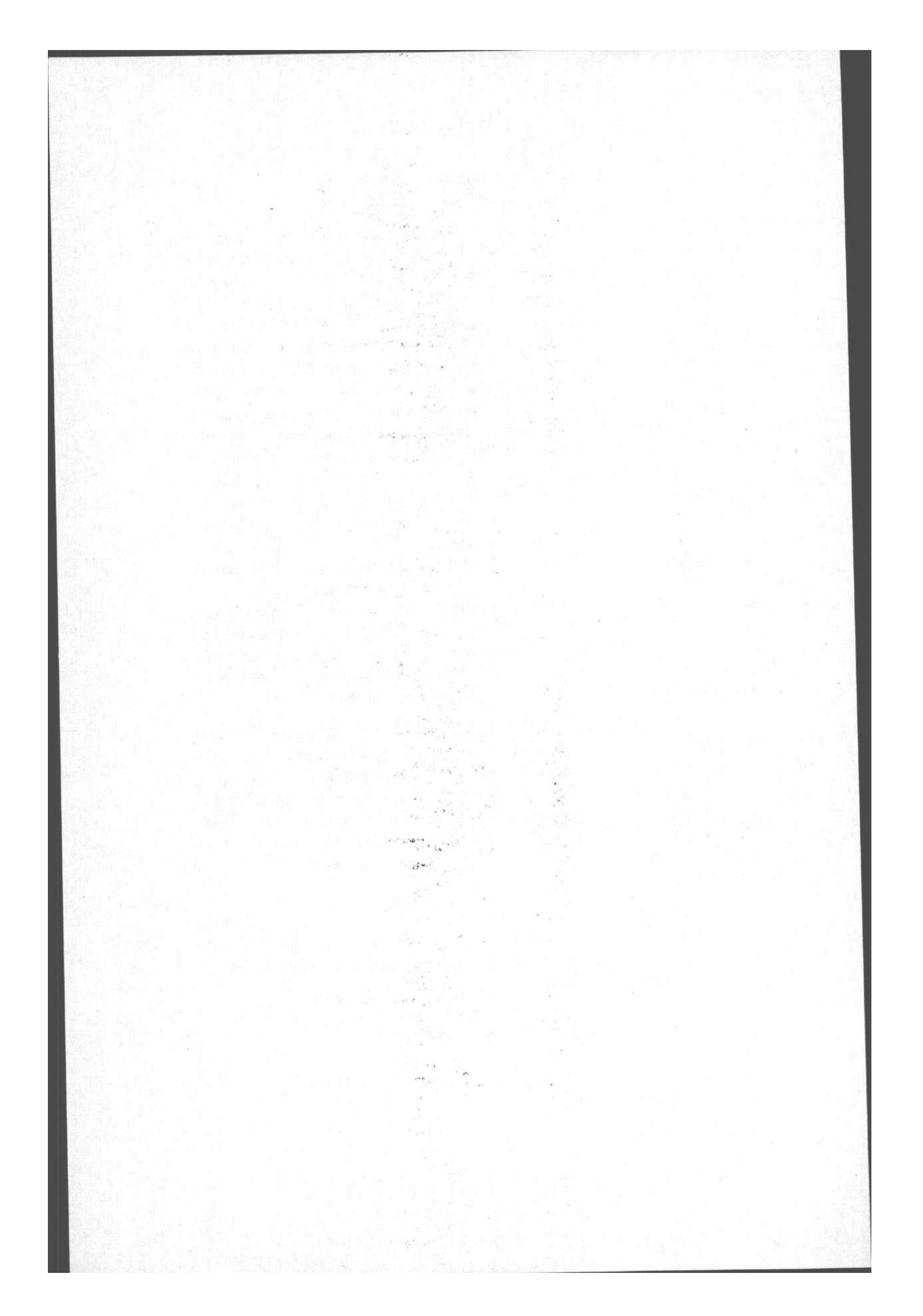

